ROCZNIKI HUMANISTYCZNE

Tom LXVII, zeszyt $10-2019$

DOI: http://dx.doi.org/10.18290/rh.2019.67.10-6

AGNIESZKA MAJEWSKA

KATHRYN NORTHEAST

\title{
PROBLEMY I WYZWANIA NAUCZYCIELI UCZĄCYCH DZIECI CUDZOZIEMSKIE WE WROCŁAWSKICH SZKOŁACH
}

Według danych z Kuratorium Oświaty we Wrocławiu w 2016 r. w szkołach wrocławskich uczyło się 2010 uczniów pochodzących z innych krajów. Są to uczniowie przyjeżdżający do Polski ze swoimi rodzicami, których migracja niejednokrotnie wiąże się z kwestiami zawodowymi. Obok mieszkających na stałe w Polsce dzieci romskich oraz polskich dzieci reemigrantów jest to grupa uczniów również mających trudności z językiem polskim. W ostatnich latach można zauważyć znaczny wzrost liczby uczniów z doświadczeniem migracji (cudzoziemców i reemigrantów znających język polski w stopniu niewystarczającym) w szkołach podstawowych i ponadpodstawowych, co stanowi nowe wyzwania dla systemu szkolnictwa.

W celu przyjrzenia się problemom powstałym w nowych warunkach od września 2017 r. do marca 2018 r. przeprowadzono na Wydziale Filologicznym Uniwersytetu Wrocławskiego ankietę, która została skierowana do nauczycieli wrocławskich szkół publicznych, a dotyczyła pracy z dzieckiem cudzoziemskim w szkole w roku szkolnym 2016/2017 .

Mgr Agnieszka Majewska - doktorantka Wydziału Filologicznego Uniwersytetu Wrocławskiego, lektorka języka polskiego w Szkole Języka Polskiego i Kultury dla Cudzoziemców UWr, nauczyciel języka polskiego jako obcego/drugiego w Zespole Szkół EKOLA Fundacji Oświatowej EKOLA i Szkole Podstawowej nr 81 im. Wandy Rutkiewicz we Wrocławiu; e-mail: agnieszka. majewska@uwr.edu.pl

Mgr Kathyryn Northeast - doktorantka Wydziału Filologicznego Uniwersytetu Wrocławskiego; e-mail: kathryn.northeast@uwr.edu.pl

${ }^{1}$ Pytania zawarte w ankiecie dotyczyły trudności uczniów niemówiących lub słabo mówiących w języku polskim z perspektywy zarówno nauczycieli, jak i uczniów, ewaluacji postępów nauczania oraz wsparcia systemowego ich edukacji w polskiej szkole. 
Łącznie uzyskano 70 odpowiedzi nauczycieli pracujących z obcojęzycznymi uczniami. Udzieliło ich 61 kobiet oraz 9 mężczyzn. Najwięcej respondentów pracowało w szkołach podstawowych (57\%), natomiast nieco mniej w gimnazjach (20\%) i szkołach średnich (20\%). Pozostali nauczyciele pracowali zarówno w szkołach podstawowych, jak i w gimnazjach. Największą grupę wśród ankietowanych stanowili poloniści (35\%).

W poniższym tekście przyglądamy się odpowiedziom respondentów na pytanie o to, jakie wyzwania mają nauczyciele uczący dzieci niemówiące lub słabo mówiące po polsku². Ponieważ pytanie to było otwarte, w niektórych odpowiedziach pisano o jednym wyzwaniu lub dwóch, w innych ankietach zaś pojawiało się ich znacznie więcej. Ze zgromadzonego materiału wyodrębniono powtarzające się zagadnienia stanowiące wyzwania dla respondentów:

1. niedoskonałości organizacyjne dodatkowych zajęć językowych (25\%);

2. brak materiałów dydaktycznych do nauczania języka polskiego jako obcego $(17 \%)$;

3. brak kwalifikacji nauczycieli do pracy z uczniami słabo znającymi język polski (10\%);

4. utrudniony kontakt $\mathrm{z}$ rodzicami, brak kontroli z ich strony $(8 \%)$;

5. ewaluacja ucznia (6\%);

6. bariera komunikacyjna między nauczycielem a uczniem (42\%);

7. poświęcanie dodatkowego czasu i uwagi uczniowi cudzoziemskiemu podczas lekcji przedmiotowych (13\%);

8. trudności ucznia (26\%).

${ }^{2}$ W swoich pracach P.E. Gębal oraz M. Pamuła-Behrens i M. Szymańska posługują się szerszym terminem ,uczniowie z doświadczeniem migracji”, obejmując nim uczniów cudzoziemskich oraz uczniów powracających do Polski po okresie migracji. Nasza ankieta zawierała pytania dotyczące wszystkich uczniów z doświadczeniem migracji (cudzoziemców oraz dzieci polskich reemigrantów), natomiast w pytaniach otwartych nauczyciele dzielili się swoimi uwagami wyłącznie na temat dzieci cudzoziemskich. 


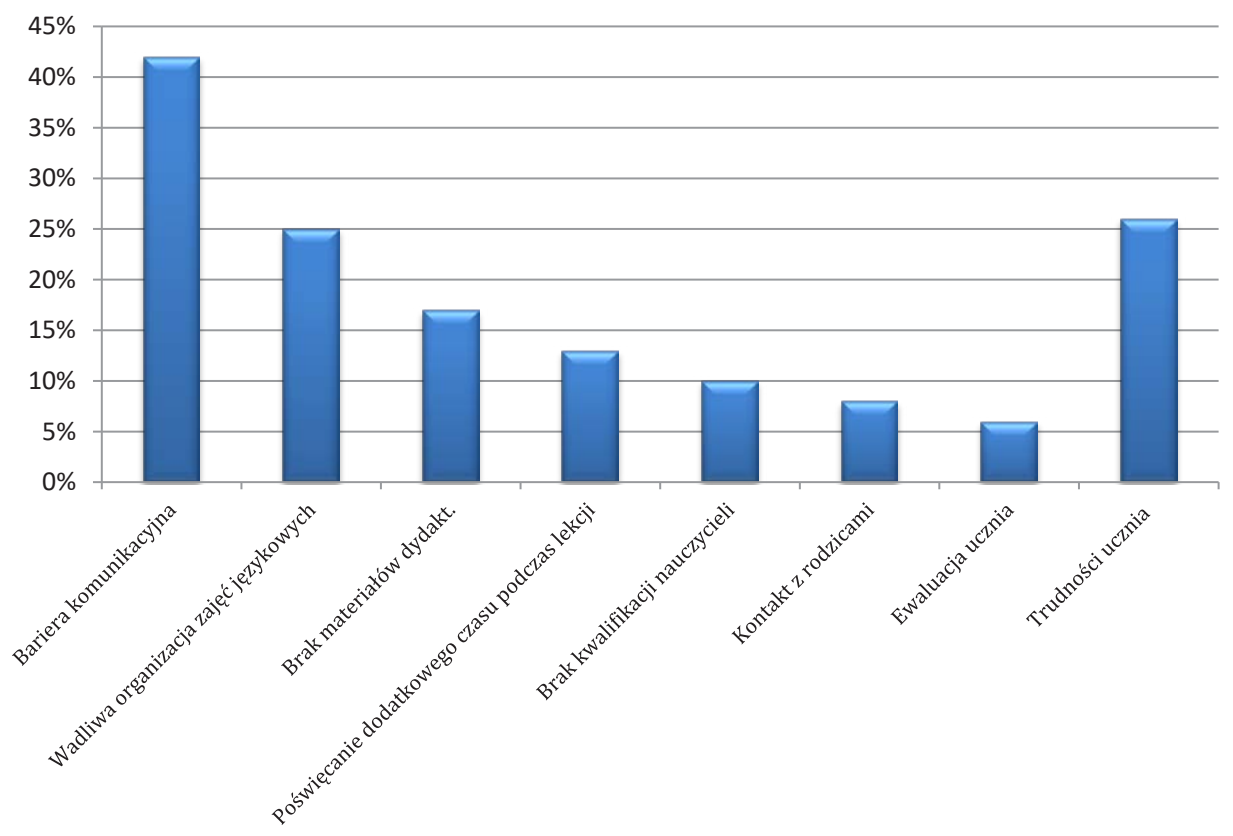

Wykres 1. ilustruje, w ilu ankietach pojawiło się dane zagadnienie w kolejności rankingowej (Trudności ucznia umieszczono na końcu, ponieważ ta odpowiedź dotyczyła problemów ucznia, a nie nauczyciela, dlatego nie uznano jej za odpowiedź na zadane pytanie).

Poniższe rozważania stanowią rozwinięcie problemów, na które respondenci zwrócili uwagę.

\section{BARIERA JĘZYKOWA MIĘDZY NAUCZYCIELEM A UCZNIEM}

W odpowiedziach 30 respondentów poruszony został problem bariery językowej sprawiającej, że uczeń nie jest w stanie skutecznie porozumieć się z nauczycielem i vice versa. Dotyczy to dwóch sytuacji: (i) komunikacji z nauczycielem prowadzącym zajęcia z języka polskiego jako obcego dla ucznia cudzoziemskiego, (ii) komunikacji z nauczycielem przedmiotowym.

Nauczyciel polonista uczący w klasach IV-V prowadzący JPJO dla dziewczynki z I klasy nie potrafi wytłumaczyć zagadnień, nie wie, w jaki sposób porozumiewać się z dzieckiem bez języka pośrednika („Dziecko mówi wyłącznie po ukraińsku. Ja tylko po rosyjsku"). Być może jest to związane z brakiem przygotowania metodycznego, podczas którego lektor zdobywa umiejętności nauczenia JPJO bez pomocy języka pośrednika. Bez wiedzy glottodydaktycznej nauczyciel-polonista, który otrzymał zadanie nauczenia ucznia cudzoziemskiego języka polskiego, jest 
dodatkowo obciążony, ale również zdezorientowany, ponieważ nie zna sposobów rozwijania kompetencji językowej ucznia bez języka pośrednika. W omówionym wyżej przykładzie nauczycielowi nie pomaga fakt, że dziecko porozumiewa się w języku ukraińskim, a sam respondent zna język rosyjski i polski. Jednak dla wielu ankietowanych ten czynnik był dość istotny. Niejednokrotnie wskazywano, że dzieci posługujące się językami słowiańskimi szybciej zaczynają komunikować się z otoczeniem, a zatem również łatwiej im porozumieć się z nauczycielem. Kilkoro ankietowanych zauważyło, że wyzwaniem jest bariera językowa z wyjątkiem sytuacji, kiedy uczeń mówi po rosyjsku lub po ukraińsku.

Ankietowani zwracali uwagę na odmienny sposób przyswajania języka przez dzieci z językiem słowiańskim jako ojczystym i dzieci z językiem ojczystym niesłowiańskim, które na początku nauki całkowicie pozbawione są możliwości rozumienia. Nauczyciele mają świadomość, że na pierwszym etapie kształcenia dziecka w szkole cudzoziemskiej podobieństwo języków zapobiega błędom komunikacyjnym i sprawia, że praca z uczniem jest łatwiejsza. Dlatego też należałoby zastanowić się nad poruszeniem zagadnienia braku języka pośrednika podczas przygotowania metodycznego nauczycieli prowadzących dodatkowe 2 godziny zajęć z uczniem cudzoziemskim. Naturalnie rzadko spotykaną sytuacją jest, że do danej szkoły poza Polakami uczęszczają jedynie Ukraińcy lub uczniowie, którzy już nauczyli się języka angielskiego. Do szkół - szczególnie w większych miastach - uczęszczają dzieci raczej z różnych krajów, których język pierwszy nie jest opanowany przez nauczycieli. Mimo to respondenci wychodzą z założenia, że nauczyciel powinien znać język ucznia. Jeden z ankietowanych wprost stwierdza: „dobrze jest, jeśli nauczyciel zna język ojczysty tych dzieci, dużo łatwiej jest wówczas nawiązać kontakt z dzieckiem i rodzicem”; inny zaś zauważa, że problemem jest nieznajomość języków obcych, ponieważ jest ich zbyt wiele, by się ich nauczyć.

Być może intuicja respondentów w tej kwestii jest do pewnego stopnia uzasadniona. Ewa Lipińska ${ }^{3}$ pisała o systemie edukacyjnym w katolickich szkołach podstawowych w Australii, który przewiduje, że uczeń cudzoziemski nie tylko otrzymuje dodatkowe godziny na lekcje z języka angielskiego prowadzone przez specjalistę, ale również według przepisów przysługuje mu pomoc ze strony tutora, który powinien być osobą dwujęzyczną. Taka osoba pomaga uczniowi wdrożyć się w nowy system, opanować materiał nauczany na zajęciach (czyli nie trzeba tego robić w czasie godzin przeznaczonych na naukę języka angielskiego), pokonać barierę komunikacyjną i ewentualne konflikty kulturowe. Obecność

\footnotetext{
${ }^{3}$ Por. E. LipiŃsKa, Polskość w Australii. O dwujęzyczności, edukacji i problemach adaptacyjnych Polonii na antypodach, Kraków: Wydawnictwo UJ 2013, s. 82-83.
} 
takiej osoby daje uczniowi poczucie bezpieczeństwa w nowych warunkach, ale również ułatwia pracę nauczycielowi przedmiotowemu, który nie musi troszczyć się o wyjaśnienie danego zagadnienia w dwóch językach (przy założeniu optymistycznego scenariusza, że nauczyciel zna rodzimy język ucznia). Jak zauważają Januszewska i Markowska-Manista ${ }^{4}$ taka instytucja jest przewidziana również w prawie polskim, jednak rzadko jest wykorzystywana w szkołach, do których uczęszczają cudzoziemcy.

\section{NIEDOSKONAŁOŚCI ORGANIZACYJNE DODATKOWYCH ZAJĘĆ JĘZYKA POLSKIEGO}

Uczniowie z doświadczeniem migracji mogą korzystać z dwóch dodatkowych godzin zajęć językowych tygodniowo nie tylko w pierwszym roku pobytu w Polsce, ale tak długo, jak długo jest potrzeba. Celem tych zajęć jest doskonalenie umiejętności językowych do poziomu umożliwiającego funkcjonowanie na lekcjach. Rodzice uczniów na początku roku składają podanie, które dyrekcja kieruje do organu prowadzącego szkołę (gminy lub powiatu w zależności od typu szkoły). Niejednokrotnie organ ten przydziela 2 godziny tygodniowo grupie uczniów na różnych poziomach kompetencji językowej i o różnych językach ojczystych (słowiańskich i niesłowiańskich). Rodzi to dużą frustrację nauczycieli, którzy nie są w stanie skutecznie uczyć języka polskiego ze względu na odmienne potrzeby i możliwości uczniów cudzoziemskich, zatem proces przyswajania wiedzy w szkole wydłuża się, a postępy są niezadowalające. W swobodnych wypowiedziach nauczyciele bardzo często zwracali uwagę na zbyt małą liczbę godzin przeznaczoną na naukę języka polskiego oraz na trudności merytoryczne w prowadzeniu zajęć dla uczniów o różnym poziomie biegłości językowej czy odmiennych językach ojczystych:

Jest za mało godzin przeznaczonych na naukę dla cudzoziemców, a na lekcji języka polskiego nie ma czasu na to, by wracać do poprzednich tematów czy tłumaczyć bieżącą wiedzę tak, by każde dziecko z innego kraju rozumiało omawiane zagadnienia.

W wielu przypadkach korzystna byłaby indywidualizacja pracy z uczniami obcojęzycznymi:

\footnotetext{
${ }^{4}$ Por. E. Januszewska, U. Markowska-Manista, Dziecko ,inne” kulturowo w Polsce. Z badań nad edukacja szkolna, Warszawa: Wydawnictwa Akademii Pedagogiki Specjalnej im. Marii Grzegorzewskiej 2017, s. 190-192.
} 
Nierówny poziom uczniów w grupach, nawet jeżeli jest podział na dwie grupy - jak jest w mojej szkole; uczniowie nierzadko wymagają pracy indywidualnej - nauki pisania i czytania. Niestety nie ma środków na pracę indywidualną. Należałoby zwiększyć liczbę godzin języka polskiego, by uczniów ominęły niepowodzenia szkolne.

Dobra organizacja dodatkowych zajęć językowych wymaga od dyrekcji szkoły wiele wysiłku. Kwestie składania podań przez uczniów i czas potrzebny na ich rozpatrzenie wydłużają moment ich rozpoczęcia. Pod uwagę należy wziąć dostępność nauczyciela, sal zajęciowych i plany lekcyjne uczniów. Zwykle dodatkowe lekcje odbywają się po zajęciach właściwych, czyli w przypadku uczniów starszych - po 7-8 lekcjach. Uczniowie są zmęczeni i trudno im się skoncentrować.

Bardzo często rola nauczyciela prowadzącego dodatkowe zajęcia językowe nie ogranicza się wyłącznie do nauczania języka polskiego jako obcego/drugiego, ale również do pomocy w nauce innych przedmiotów szkolnych:

Dużym problemem dla nauczyciela i ucznia jest to, że należy uczyć nie tylko języka polskiego, ale równocześnie na bieżąco realizować programy nauczania z różnych przedmiotów, które mają swoją specyfikę, np. terminologię. Z moim uczniem odrabiałam lekcje, tłumacząc polecenia, wyjaśniając znaczenie pojęć matematycznych, przyrodniczych.

Uczniowie często zgłaszają swoje trudności w nauce przedmiotów szkolnych nauczycielom prowadzącym dodatkowe lekcje języka polskiego, ponieważ pedagodzy z przygotowaniem metodycznym w zakresie glottodydaktyki posiadają wiedzę na temat procesów akwizycji języka obcego/drugiego i lepiej rozumieją trudności uczniów obcojęzycznych, a co za tym idzie - mogą im skuteczniej pomagać.

Jako rozwiązanie kwestii przyjmowania do polskich szkół uczniów obcojęzycznych respondenci wielokrotnie podawali konieczność stworzenia oddziałów przygotowawczych:

[...] Niektórzy uczniowie rozpoczynają naukę w trakcie roku szkolnego i bez podstawowej znajomości języka polskiego. Nie są w stanie opanować podstawy programowej. [...] Rok przygotowawczy do podjęcia pełnej nauki (w pełnym wymiarze godzin i ze wszystkimi wymaganymi przedmiotami) poświęcony głównie na intensywną naukę języka polskiego (ewentualnie z włączeniem przedmiotów artystycznych i WF) byłby sensownym rozwiązaniem. 
Takie oddziały - zdaniem nauczycieli - ułatwiłyby obcokrajowcom funkcjonowanie w polskiej szkole i ograniczyły negatywne skutki związane ze zmianą środowiska szkolnego:

Uczniowie niemówiący po polsku powinni co najmniej przez rok uczyć się tylko języka polskiego. Nie radzą sobie ze słownictwem danego przedmiotu - np. na historii, biologii itd. Jest im bardzo ciężko, rodzice wielokrotnie nie rozumieją tego. Dzieci są pod ogromną presją.

Od września 2017 r. prawo dopuszcza możliwość tworzenia wspominanych wielokrotnie przez respondentów oddziałów przygotowawczych.

\section{BRAK MATERIALÓW DYDAKTYCZNYCH DO NAUCZANIA JĘZYKA POLSKIEGO JAKO OBCEGO/DRUGIEGO}

Dla nauczycieli bez doświadczenia w pracy z uczniami obcojęzycznymi dużym wyzwaniem może być przygotowanie odpowiednich materiałów dydaktycznych. Wybór na rynku wydawniczym z roku na rok jest coraz większy. Najwięcej podręczników i ćwiczeń kierowanych jest do uczniów ukraińskojęzycznych na różnych poziomach biegłości językowej. Wiele z nich powstało dzięki finansowaniu fundacji i są dostępne bezpłatnie online (np. red. P. Garncarek $A$ to polski właśnie, https://pol.org.pl/a-to-polski-wlasnie-pobierz-podrecznik/, K. Kołak, M. Malinowska, A. Rabczuk, D. Zackiewicz Raz, dwa, trzy i po polsku mówisz ty!, Podręcznik do nauki języka polskiego dla dzieci na Ukrainie https://wid. org.pl/podrecznik/, R. Ciesielska, K. Kwiatkowska, M. Maćkowiak, Język polski bez granic, http://www.wspolnotapolska.org.pl/bezgranic/index.php?fbclid=IwA R3EYEaOAvvVgq2vTXENz0hyYNEI1-d0Jy7Np5PD1iYEddmVyZATrKnIp_k).

Zdecydowanie mniej materiałów i pomocy dydaktycznych powstało dla uczniów niesłowiańskojęzycznych. Dla dzieci młodszych najczęściej wykorzystywanym podręcznikiem jest Lubię polski A. Rabiej. W nauczaniu cudzoziemców ze szkół podstawowych największą popularnością cieszy się seria podręczników i materiałów Polski, krok po kroku junior autorstwa M. Grudzień, P. Kuc oraz I. Stempek. Podręcznik przewidziany jest jednak tylko na 60 godzin nauki. Obydwa podręczniki kierowane są do uczniów początkujących. Na rynku wydawniczym brakuje materiałów do nauczania dzieci i młodzieży niesłowiańskojęzycznych od poziomu biegłości A2. Nie powstały również materiały służące rozwijaniu czy doskonaleniu poszczególnych sprawności, np. pisania, co stanowi duże wyzwanie w przypadku uczniów nieposługujących się alfabetem łacińskim. 
Część pomocy dydaktycznych dla osób dorosłych można zaadaptować na potrzeby uczniów, jednak może to sprawić trudność polonistom bez kwalifikacji glottodydaktycznych ze względu na stosowanie odmiennych metod, treści nauczania i nieznajomość tych materiałów dydaktycznych. $Z$ tego względu respondenci wielokrotnie wskazywali tę kwestię jako wyzwanie dla nauczyciela: „Brak doświadczenia i znajomości metod pracy z takimi uczniami. Konieczność samodzielnego wyboru i przygotowywania materiałów (brak podręczników i pomocy)". Ponadto prowadzenie zajęć w zróżnicowanej językowo grupie wyklucza możliwość korzystania z jednego podręcznika i wymusza sięganie do różnych źródeł, co wiąże się z dodatkową pracą nauczyciela prowadzącego.

\section{POŚWIĘCANIE DODATKOWEGO CZASU I UWAGI UCZNIOWI CUDZOZIEMSKIEMU PODCZAS LEKCJI PRZEDMIOTOWYCH}

Jednym $z$ aspektów opisanej wyżej bariery językowej, który pojawia się w pracy nauczyciela przedmiotowego, jest dodatkowe poświęcenie czasu $\mathrm{i}$ indywidualnej uwagi dziecku cudzoziemskiemu podczas lekcji. Wiele odpowiedzi respondentów wskazywało na trudności związane z koniecznością tłumaczenia danego zagadnienia w dwóch językach:

Prowadzenie zajęć z uczniem bardzo słabo mówiącym po polsku podczas lekcji języka znajdujących się w planie klasy w sytuacji obecności kilkunastu lub - ponad 20 uczniów, którzy w momencie tłumaczenia materiału obcokrajowcowi często przeszkadzają, zakłócając komunikację; utrudniona komunikacja z uczniami, dodatkowe tłumaczenie zadań; konieczność prowadzenia lekcji w dwóch językach.

Jeden $\mathrm{z}$ respondentów zwrócił uwagę na trudności, jakie ma w zrozumieniu wypowiedzi ucznia, oraz na to, że uczeń odrabia zadanie domowe w swoim języku rodzimym i nauczyciel nie może wówczas prawidłowo ocenić zadania.

Bariery te stanowią wyzwanie dla nauczyciela, głównie dlatego że musi on poświęcać swój czas i uwagę, a długość lekcji pozostaje taka sama. Jest to problem, na który uwagę zwróciło dziewięciu ankietowanych, a który wydaje się kwestią do rozwiązania nie metodycznie, a technicznie. Jeżeli nauczyciel nie wytłumaczy cudzoziemcowi materiału, zrealizuje przygotowany przez siebie materiał w odpowiednim czasie, ale uczeń będzie pozostawiony sobie (bądź kolegom z klasy, którzy zamiast się koncentrować na zagadnieniu, będą starali się mu pomóc) i to 
stanowi fundament pod nawarstwianie się zaległości ${ }^{5}$. Nauczyciel może również poświęcić czas na wytłumaczenie uczniowi cudzoziemskiemu zagadnienia, ale wówczas może nie zrealizować tematu, a w dłuższej perspektywie kilkunastu takich niedokończonych lekcji cała klasa będzie miała zaległości. Dlatego żadne rozwiązanie nie wydaje się tutaj doskonałe. Niejednokrotnie uczeń zostaje pozostawiony sobie, a materiał jest przyswajany na dwóch dodatkowych lekcjach w tygodniu, które powinny być przeznaczone na naukę języka polskiego. Jeden $\mathrm{z}$ respondentów wskazał wprost, że bariery komunikacyjne uniemożliwiają normalną naukę przedmiotów, a inny stwierdził, że „największym wyzwaniem dla nauczyciela uczącego dziecko z innego kraju jest przekazanie w sposób zrozumiały dla dziecka pożądanych treści”. Wszystkie wypowiedzi wskazują na to, że nauczyciele czują na sobie obowiązek przekazania wiedzy, ale z powodu problemów komunikacyjnych nie są w stanie sprostać temu zadaniu i stają się bezradni wobec problemów ucznia. Wydaje się, że w tej sytuacji nauczycielom brakuje asystenta, który towarzyszyłby uczniowi cudzoziemskiemu w pierwszej fazie, kiedy są największe bariery językowe.

\section{BRAK KWALIFIKACJI, PRZYGOTOWANIA MERYTORYCZNEGO NAUCZYCIELI DO PRACY Z UCZNIAMI OBCOJĘZYCZNYMI}

Respondentów zapytano także o to, kto w ich placówkach prowadzi dodatkowe zajęcia językowe dla uczniów cudzoziemskich. Na pytanie odpowiedziało 67 ankietowanych. Okazało się, że w szkołach lekcje z języka polskiego dla uczniów cudzoziemskich prowadzą najczęściej poloniści zatrudnieni na etacie bez specjalizacji z nauczania języka polskiego jako obcego (52\%). 21\% prowadzących to poloniści zatrudnieni na etacie i posiadający dodatkowe kwalifikacje w zakresie glottodydaktyki, 1,5\% stanowili nauczyciele z kwalifikacjami, zatrudnieni dorywczo w danej szkole. Nieco wyższy odsetek odpowiedzi dotyczył prowadzenia dodatkowych zajęć językowych przez nauczycieli neofilologów, wynosił on 4,5\%. $21 \%$ respondentów wskazało inny wariant. Wśród nich znaleźli się: nauczyciele edukacji wczesnoszkolnej (14\%), logopedzi (3\%), terapeuta (1\%) i nauczyciel, który odbył szkolenie (1\%).

Ankietowani otwarcie przyznawali, że brakuje im kwalifikacji w zakresie nauczania dzieci cudzoziemskich:

\footnotetext{
${ }^{5}$ Por. Tamże, s. 181-183.
} 
Nie posiadam jako nauczyciel edukacji wczesnoszkolnej wiedzy na temat tego, jak uczyć języka polskiego obcokrajowców. Brakuje mi przygotowania metodycznego w tym zakresie. Uczę dzieci według swoich metod jako kontynuacja tego, co robimy w czasie lekcji.

Ankietowani często zauważali potrzebę doszkalania całego grona pedagogicznego: „Podstawowe szkolenie na temat pracy z dziećmi cudzoziemskimi powinni przejść wszyscy nauczyciele w szkole". Ponadto niektórzy badani wskazywali na brak wsparcia merytorycznego i możliwości konsultacji z metodykiem.

P.E. Gębal również zauważa brak skoordynowanego kształcenia nauczycieli języka polskiego jako drugiego:

Podejmowane w niektórych ośrodkach akademickich kształcenie nauczycieli języka polskiego jako drugiego ma charakter nieskoordynowany i stanowi zwykle uzupełnienie oferty przygotowującej do pracy w charakterze lektora języka polskiego jako obcego o wybrane aspekty dydaktyki polszczyzny jako języka drugiego. W formalnym wymiarze pedentologicznym owo kształcenie praktyczne wciąż nie istnieje. W nauczaniu języka polskiego w Polsce nadal nie ma świadomości języka polskiego jako drugiego. ${ }^{6}$

\section{UTRUDNIONY KONTAKT Z RODZICAMI, BRAK KONTROLI Z ICH STRONY}

Kolejnym zagadnieniem pojawiającym się w wypowiedziach nauczycieli biorących udział w ankiecie była kwestia kontaktów z rodzicami uczniów cudzoziemskich. Ankietowani wyraźnie zwracali uwagę na trudności związane z porozumiewaniem się z rodzicami dzieci cudzoziemskich mające wpływ na proces kształcenia tych uczniów. Głównym powodem wskazywania tego problemu jest brak wsparcia w nauce przez rodziców i kontroli z ich strony ze względu na nieznajomość języka polskiego: „[...] Innym problemem jest to, że większość z tych dzieci nie ma pomocy w domu, ponieważ ich rodzice nie chcą szkolić języka. Bez tej współpracy uczniowie bardzo powoli uczą się języka i mają trudności w szkole".

\footnotetext{
${ }^{6}$ P.E. GĘBAL, Podstawy dydaktyki języka polskiego jako drugiego. Podejście integracyjno-inkluzyjne, Kraków: Księgarnia Akademicka 2018, s. 93.
} 
Jak zauważa Marzena Wysocka ${ }^{7}$, rodzice odgrywają niejednokrotnie kluczową rolę w procesie nauczania. Są oni nie tylko odpowiedzialni za monitorowanie i kontrolę pracy ucznia, ale również za pomoc w organizacji przestrzeni i czasu pracy. Jeżeli rodzicowi nie zależy na nauce języka polskiego swojego dziecka, będzie to widoczne w efektach pracy. Jest to niezwykle istotne, ponieważ w niektórych przypadkach dochodzi do sytuacji, w których rodzice słabo znający lub nieznający języka kraju pobytu tracą autorytet swoich dzieci ${ }^{8}$, które coraz lepiej posługują się językiem kraju zamieszkania, stając się dwujęzyczne. Skutkiem tego mogą być rzadsze wizyty rodziców w szkole spowodowane zakłopotaniem ich dzieci lub - w skrajnych przypadkach - problemy wychowawcze.

\section{SPOSÓB EWALUACJI UCZNIA CUDZOZIEMSKIEGO}

Kolejnym wyzwaniem, przed którym stoją nauczyciele różnych przedmiotów, jest ocenianie uczniów z doświadczeniem migracji: „Nie wiadomo, jak oceniać przyrost wiedzy i umiejętności szczególnie z takich przedmiotów jak: j. polski, historia, przyroda". Szczególnie trudne jest to na początku pobytu oraz w przypadkach, kiedy bariera językowa utrudnia komunikację z nauczycielem. Zwykle sprawdzenie wiedzy ucznia o niewystarczającej kompetencji językowej wymaga od uczących dodatkowej pracy. Dokumenty prawne nie określają sposobu oceniania uczniów o niewystarczającej kompetencji językowej. Przepisy nie regulują sposobu oceniania uczniów słabo znających język polski: w $§ 8$. i 12. Rozporządzenia Ministra Edukacji Narodowej z dnia 3 sierpnia 2017 r. (Dz.U. 2017 poz. 1534) w sprawie oceniania, klasyfikowania i promowania uczniów i słuchaczy w szkołach publicznych nie ma rozdziału kryteriów oceny ze względu na poziom znajomości języka polskiego.

Z rozmów z nauczycielami wynika, że przyjmują oni różne strategie w ocenianiu uczniów obcojęzycznych: np. egzekwują wiedzę w formie ustnej, przygotowują specjalne wersje testów (wyłącznie pytania zamknięte) lub polecają wykonanie tylko części zadań przygotowanych dla całej klasy. Niektórzy nauczyciele uważają jednak, że uczniowie cudzoziemscy nie powinni być traktowani ulgowo w polskiej szkole, więc nie stosują wobec nich odrębnych kryteriów oceny. Problemy

\footnotetext{
${ }^{7}$ Por. M.S. WysockA, Who are the significant others in the learning process? „Linguistica Silesiana" 2007, nr 28, s. 267-279.

${ }^{8}$ T. Schofield, K. Beaumont, K. Widaman, R. Jochem, R. Robins, R. Conger, Parent and child fluency in a common language: implications for the parent-child relationship and later academic success in Mexican American families, „Journal of Family Psychology” 2012, nr 26(6), s. 869-879.
} 
zaczynają pojawiać się wtedy, kiedy uczeń ze względu na barierę językową, a nie brak wiedzy, otrzymuje ocenę negatywną na koniec roku szkolnego.

Zdarza się, że polscy uczniowie nie rozumieją sytuacji swoich obcojęzycznych kolegów, z którymi poza lekcjami mogą się porozumiewać bez większych problemów. Niejednokrotnie mają zastrzeżenia lub wątpliwości, zastanawiając się, dlaczego ci uczniowie otrzymują lepsze oceny od nich, choć wymagania wobec nich są mniejsze.

\section{TRUDNOŚCI UCZNIA}

\section{a) Problemy komunikacyjne}

Niektórzy respondenci nie odpowiedzieli dokładnie na pytanie o wyzwania nauczycieli, ponieważ w swoich odpowiedziach pisali o trudnościach uczniów, a ściślej - o trzech aspektach tych trudności: nierozumienie języka, niemówienie w języku polskim oraz wyobcowanie.

Nierozumienie języka polskiego oraz nieposługiwanie się nim ściśle wiąże się z wyżej omówionymi problemami, a mianowicie z barierami językowymi w komunikacji z nauczycielami przedmiotowymi i polonistami prowadzącymi dwie dodatkowe godziny z języka w tygodniu. Na takie trudności wskazano w 23 ankietach (33\%). Trudności komunikacyjne ucznia są jednocześnie wyzwaniem (również komunikacyjnym) nauczyciela.

\section{b) Wyobcowanie}

Kilkoro nauczycieli wskazywało na trudności ucznia związane z wyobcowaniem. Zwracali uwagę na alienację w grupie rówieśniczej. Osamotnienie w środowisku szkolnym sprawia, że z jednej strony dziecko przestaje starać się na lekcjach przedmiotowych, ale również jest to czynnik afektywny uczenia się języka polskiego jako obcego. Magdalena Szpotowicz ${ }^{9}$ zauważa, że w warunkach szkolnych dziecko nie ma oporów przed uczeniem się języka jako obcego do ok. 10 roku życia. Inaczej jednak jest, gdy dziecko uczy się języka polskiego jako drugiego w naturalnych warunkach zanurzenia językowego. Wówczas nauka może wydawać się łatwiejsza ze względu na stały kontakt z językiem, jednak może być ona również hamowana ze względu na wzmocnienie niechęci do języka wskutek wyobcowania w grupie rówieśniczej.

\footnotetext{
${ }^{9}$ M. Szpotowicz, Proces uczenia się dzieci w przedszkolu i szkole podstawowej, w: Nauka języka obcego w perspektywie ucznia, red. H. Komorowska, Warszawa: Oficyna Wydawnicza ŁOŚGRAF - Wiesław Łoś 2011, s. 123-139.
} 
Zadaniem nauczyciela wydaje się odpowiednia i rozsądna ocena sytuacji. Wyobcowanie może wynikać z odrzucenia przez grupę, ale również z zachowania ucznia. Może być związane z cechami indywidualnymi ucznia, jego osobowością. Wówczas alienacja ucznia miałaby miejsce również w kraju jego pochodzenia. W każdej sytuacji należy dochodzić przyczyn wyobcowania, żeby je zminimalizować. Jeśli wyobcowanie wynika z bariery językowej między uczniem a jego rówieśnikami, wychowawca może zaproponować zabawy integracyjne w klasie lub ćwiczenia polegające na komunikacji niewerbalnej.

\section{c) Realizacja podstawy programowej}

Pierwszym wyzwaniem, przed którym zostaje postawiony uczeń z doświadczeniem migracji, jest udział w zajęciach szkolnych, a co za tym idzie - konieczność rozumienia i posługiwania się językiem edukacji szkolnej. Jest to język niezbędny do zdobywania wiedzy. Jego znajomość jest konieczna do rozumienia i używania tekstów specjalistycznych, które znajdują się w podręcznikach szkolnych, a powiązane są z różnymi dziedzinami wiedzy (np. historią, fizyką, geografią itd.) i nasycone są specyficzną terminologią. Teksty te charakteryzuje składnia nietypowa dla języka komunikatywnego, nieformalnego. Proces nabywania języka edukacji szkolnej jest długotrwały i wymaga około 5-7 lat kształcenia. Przyswojenie języka używanego w codziennej komunikacji zajmuje zwykle około 2 lat. Długość tego okresu jest przybliżona i zależy od wielu czynników ${ }^{10}$.

Dla wielu nauczycieli sprawność językowa w kontaktach pozalekcyjnych jest wyznacznikiem ogólnej biegłości językowej. Jest to bardzo mylące przekonanie. Często uczniowie słowiańskojęzyczni zaczynają się uczyć języka polskiego jeszcze przed przyjazdem do Polski, ale niejednokrotnie okazuje się, że ich kompetencja językowa jest niewystarczająca, żeby swobodnie uczestniczyć we wszystkich zajęciach przedmiotowych: „Nie rozumieją co mówię, więc z fizyką też sobie nie radzą. Brak im podręczników w ojczystym języku".

Rozbieżność ta jest szczególnie zauważalna w przypadku uczniów powracających z migracji, którzy swobodnie posługują się językiem codziennej komunikacji, ale mają duże trudności w rozumieniu i posługiwaniu się językiem edukacji szkolnej, ponieważ ich dotychczasowe kształcenie przebiegało w innym języku.

Uczniowie z doświadczeniem migracji nie znają terminologii charakterystycznej dla różnych przedmiotów szkolnych i ze względu na braki w kompetencji językowej nie znają również kontekstów z poprzednich poziomów edukacji,

\footnotetext{
${ }^{10}$ M. PamuŁa-Behrens, M. Szymańska, W polskiej szkole. Materiaty do pracy z uczniami z doświadczeniem migracji. Przewodnik, http://filpolska.up.krakow.pl/wp-content/uploads/2018/03/ PRZEWODNIK-W-POLSKIEJ-SZKOLE.pdf, 2007, s. 12.
} 
do których odwołują się nauczyciele. Powoduje to nawarstwianie się kolejnych trudności.

Każdemu uczniowi w ciągu pierwszego roku przysługują maksymalnie 3 godziny zajęć wyrównawczych z trzech przedmiotów Jeśli jednak kompetencja językowa takiego ucznia jest bardzo niska i nie ma możliwości kontaktu z nauczycielem w języku pośredniku, to cel jest trudny w realizacji, ponieważ uwaga uczących koncentruje się na bieżącym materiale przedmiotowym, który należy przyswoić, aby uzyskać pozytywną ocenę na koniec semestru lub roku szkolnego. Duży problem stanowią lekcje języka polskiego, a przede wszystkim czytanie lektur szkolnych. Język tekstów literackich stanowi często wyzwanie dla uczniów słowiańskojęzycznych, a barierę nie do pokonania dla pozostałych. Lista lektur obowiązkowych na egzaminie ósmoklasisty jest taka sama zarówno dla uczniów polskojęzycznych, jak i dla cudzoziemców.

Bardzo ważnym czynnikiem jest wiek ucznia przybywającego do polskiej szkoły. Uczniowie młodsi, szczególnie w klasach I-III, mają większe szanse na powodzenia, ponieważ ich edukacja przebiega systematycznie i stopniowo. Im uczeń jest starszy, tym większe trudności napotyka. Rozpoczynając naukę w polskiej szkole w VII czy VIII klasie, uczeń musi pokonać barierę językową oraz nawarstwiający się materiał do opanowania pod kątem egzaminu ósmoklasisty, który szczegółowo określa podstawa programowa: „Największym wyzwaniem jest indywidualizacja pracy podczas lekcji, ponieważ nieznajomość języka nie zwalnia dzieci z realizacji zapisów podstawy programowej”.

\section{ZAKOŃCZENIE}

Przedstawione w artykule zagadnienia nie wyczerpują tematu trudności i wyzwań związanych z nauczaniem dzieci obcojęzycznych w polskiej rzeczywistości szkolnej. Zauważalne są już pewne działania w zakresie szerzenia wiedzy o pracy z uczniami z doświadczeniem migracji chociażby w postaci metody JES-PL oraz cyklu szkoleń dotyczących uczniów migrujących organizowanych przez Ośrodek Rozwoju Edukacji, ale ich skala jest zbyt mała, aby doraźnie wspomóc nauczycieli, którzy na co dzień borykają się z wieloma problemami. Korzystna byłaby również stała współpraca instytucji i specjalistów od edukacji w Polsce z reprezentantami glottodydaktyki polonistycznej. 


\section{BIBLIOGRAFIA}

G̨̨BAL P.E., Podstawy dydaktyki języka polskiego jako drugiego. Podejście integracyjno-inkluzyjne, Kraków: Księgarnia Akademicka 2018.

LipińsKa E., Polskość w Australii. O dwujęzyczności, edukacji i problemach adaptacyjnych Polonii na antypodach, Kraków: Wydawnictwo UJ 2013.

Pamula-Behrens M., Szymańska M., W polskiej szkole. Materiaty do pracy z uczniami z doświadczeniem migracji. Przewodnik. http://filpolska.up.krakow.pl/wp-content/uploads/2018/03/ PRZEWODNIK-W-POLSKIEJ-SZKOLE.pdf (dostęp: 30.02.2019).

Schofield T., Beaumont K., Widaman K., Jochem R., Robins R., Conger R., Parent and child fluency in a common language: Implications for the parent-child relationship and later academic success in Mexican American families, „Journal of Family Psychology” 2012, nr 26(6), s. 869-879.

SzPotowicz M., Proces uczenia się dzieci w przedszkolu i szkole podstawowej, w: Nauka języka obcego w perspektywie ucznia, red. H. Komorowska, Warszawa: Oficyna Wydawnicza ŁOŚGRAF - Wiesław Łoś 2011, s. 123-139.

WysocKa M.S., Who are the significant others in the learning process?, „Linguistica Silesiana” 2007, nr 28, s. 267-279.

Januszewska E., Markowska-Manista U., Dziecko „inne” kulturowo w Polsce. Z badań nad edukacja szkolna, Warszawa: Wydawnictwa Akademii Pedagogiki Specjalnej im. Marii Grzegorzewskiej 2017.

\section{PROBLEMY I WYZWANIA NAUCZYCIELI \\ UCZĄCYCH DZIECI CUDZOZIEMSKIE WE WROCŁAWSKICH SZKOŁACH}

Streszczenie

W ciągu ostatnich lat możemy zaobserwować wzrastającą liczbę uczniów cudzoziemskich w polskich szkołach. Ten wzrost wiąże się zarówno z powrotem rodzin polskich z emigracji zarobkowej, jak również z podjęciem pracy przez obcokrajowców w Polsce. Artykuł stanowi próbę omówienia wyzwań nauczycieli pracujących z cudzoziemcami we wrocławskich szkołach. Na podstawie ankiety przeprowadzonej w szkołach w 2018 r. autorki tekstu wyodrębniły najważniejsze wyzwania przywołane przez nauczycieli: problem porozumienia się z uczniem wskutek bariery językowej, niedoskonałość organizacji dodatkowych zajęć językowych, poświęcanie dodatkowego czasu i uwagi uczniom cudzoziemskim podczas innych lekcji, brak przygotowania merytorycznego nauczycieli, ograniczony kontakt z rodzicami uczniów, trudności związane z obiektywną oceną pracy ucznia oraz trudności komunikacyjne, emocjonalne i merytoryczne samego ucznia.

Słowa kluczowe: nauczanie języka polskiego jako obcego; uczeń cudzoziemski w szkole; wyzwania nauczycieli. 


\section{PROBLEMS AND CHALLENGES OF TEACHERS TEACHING FOREIGN CHILDREN IN SCHOOLS OF WROCŁAW}

S u m m a r y

'In recent years, we can observe an increasing number of foreign students in Polish schools. This phenomenon is connected both to the return of Polish families from economic emigration as well as to foreigners coming to work in Poland. The paper is an attempt to discuss the challenges of teachers working with foreigners in schools in Wrocław. On the basis of a survey conducted in schools in 2018, the authors identified the most important challenges raised by teachers: the problem of communicating with the pupil due to language issues, faulty organization of additional language classes, dedicating additional time and attention to foreign students during different subjects, lack of teaching materials, limited contact with the pupils' parents, difficulties related to an objective assessment of the pupil's work and emotional and substantive and communication-based difficulties of the students themselves.

Key words: teaching Polish as a foreign language; foreign student at school; teachers' challenges. 